\title{
Inhibition of multidrug resistance related protein by acetyl salicylic acid in cultured human lung cells
}

\author{
Abdelrahman Torky ${ }^{1,2}$, Ayman Kamar ${ }^{2}$, and Heidi Foth ${ }^{1}$ \\ ${ }^{1}$ Institute of Environmental Toxicology, Halle University, D-06097 Halle / Saale, Germany \\ ${ }^{2}$ Department of Forensic Medicine and Clinical Toxicology, Faculty of Medicine, Helwan \\ University, Egypt \\ Corresponding Author: Dr. Abdelrahman Torky \\ E-mail: abdeltorky30@gmail.com \\ Postal address: Department of Forensic Medicine and Clinical Toxicology, Faculty of \\ Medicine, Helwan University. Helwan, Egypt. \\ Telephone: +201017836219
}

\begin{abstract}
BACKGROUND: Multidrug resistance related proteins (MRP-proteins), members of the ATP binding cassette (ABC-) superfamily, are known to play an important role in regulation of glutathione homeostasis within cells, and hence in GSH dependent transport processes of xenobiotics. Many airborne compounds are hazardous inducing inflammatory reactions in lung and are suspected to play a substantial role in initiation and/or promotion of tumor formation. It is interesting to clarify whether and how anti-prostaglandins modify MRP function in normal human lung cells. Aspirin, an acetylated salicylate, is classified among the non-steroidal anti-inflammatory drugs (NSAIDs), reduce inflammatory signs and symptoms exhibiting a broad range of pharmacological activities (analgesic, antipyretic and antiplatelet properties). Cyclooxygenase (COX)-system catalyses the rate limiting step in prostanoids (prostaglandin (PG)) synthesis and is also involved in drug resistance and poor prognosis of many neoplastic diseases. Aspirin's ability to suppress prostaglandins and thromboxanes production is due to its irreversible inactivation of the cyclo-oxygenase (COX) enzyme. Furthermore, transport activity study of MRP1 in NHBEC, PLC and A549 under the effect of exogenously supplied PGE2 showed an increased activity. METHODOLOGY and RESULTS: In this study, both the localisation and description of the cellular distribution of MRP-1 under standard culture conditions in normal human bronchial epithelial cells (NHBEC), peripheral lung cells (PLC) and tumor lung cells (A549) was proved using indirect immunofluorescence microscopy. All substrates and incubation periods have been prechecked for cellular toxicity in the MTT assay in order to guarantee that non toxic conditions are applied. CONCLUSION: COX inhibitor (acetylsalicylic acid 1,2mM) could significantly decrease the transport activity of MRP1 in NHBEC, PLC and A549 in 1 and 3 days trials.
\end{abstract}

KEYWORDS: Human lung cells, MRPs, Immuncytochemistry, Transport, PGs, COX inhibitors.

\section{INTRODUCTION}

Years ago, membrane transport studies have been undergoing continuous specialization regarding cell and tissue transporters especially cellular transport physiology 
inparticularbiologically active cells and tissues. Different tissues often reacted differently to the same conditions on grounds of varying combinations of a limited number of transport mechanisms. One of the grand $\mathrm{ABC}$ transporter families, the Multidrug Resistance Related Protein (MRP) subfamily that comprises not less than 9 members (Kool et al., 1997; Müller 2002; Sampath et al., 2002, Roy et al., 2015; Gana et al., 2019).

Multidrug Resistance-Related Proteins (MRPs) are genetically related trans-membrane proteins where some are functionally uncharacterized while many are shown to mediate an ATP linkedefflux of organic anions from cells contrary to concentration gradient (Borst et al., 1999; Borst et al., 2000; Sampath et al., 2002, Roy et al., 2015).

Of this subfamily, MRP1-6 are the best investigated members. MPR1 plays an important physiological role in protecting certain tissues from chemotherapeutic effects as well as in inflammatory reactions and antigenpresenting "dendritic" cell function. MRP2 is incorporated in hepatobiliary clearance of conjugated bilirubin. MRP3 confers resistance to epipodophyllotoxins and acts as a part in the pathologic disposition of bile acids. Glutathion-, glucuronate- or sulfate- conjugates of lipophilic compounds are physiological substrates of MRP1-3. MRP1-4pumps representeffective resistance factors for diverse chemotherapeutic drugse.g. methotrexate, and MRP1 may be involved in maintaining folate homeostasis. MRP4, 5 and 8 are cellular efflux pumps that provide resistance to nucleotide analogs. MRP6 transports, not only glutathione conjugates, but also is a broad-spectrum porphyrin transporter.MRP9has structural similarity to MRP4, 5 and 8, so that the possibility of sharing some of the properties of the latter is raised. Therefore, mammalian MRPs may help in protecting their host cells against toxic substances especially lung cells, not only because it is a target organ for many air borne toxic xenobiotics but also as a portal of entry for inhaled toxins(Leier et al., 1994; König et al., 1999; Zeng et al.,2000; Belinsky et al., 2002; Jedlitschky and Keppler, 2002; Kruh and Belinsky, 2003; Haimeur et al., 2004; Niest et al., 2004; Roy et al., 2015; Teodori et al., 2015).

Environmental pollutants have been found to intiate inflammatory responsein pulmonary mucosa. Prostaglandins (PGs) are biologically active lipid-derived autacoids synthesized through a sequential enzymatic metabolism of arachidonic acid. Structurally different PGsare described as potent (pro)inflammatory mediators. Cyclooxygenase (COX)system is the catalyst of the rate limiting step in PG synthesis (clinically characterised as target for the action of non-steroidal anti-inflammatory drugs (NSAIDs)). Studies also showed a definite association between COXsystem and malignancy with augmented PG production as well as its involvement in endogenous regulation of mdr1 gene. PGF2 and PGE2 stimulated the in-vitro expression of the ABC transport protein Pgp (mdrlb) in rat hepatocytes in culture, and the COX-system inhibitors modulate the transport activity of this protein. 
Together, there is a regulatory inter-linkage between inflammatory mediators "PGs" and COX enzymes, on one side, and cellular detoxifying transporters "MRPs", on the other (Ziemann et al., 2002; Liu et al, 2009).

Since most human cells express one or more MRP isoforms, cellular expression patterns have to be clarifiedto uncover the potential biological functions of MRPs membrane integral pumps. Presence of MRP transporters in the lung may prevent toxin accumulation in lung cells, but at the same time, it constitutes a portal of entry for inhaled xenobiotics through basolateral transport.

A sensitive non-invasive fluoresence assay was developed (Stehfest et al., 2005; Torky et al., 2008) that can determine the functional activity of MRP proteins in attached cells; a suitable method to interpret main effects and toxicological relevance of MRP-inducers or suppressors e.g. COX enzymes inhibitors.In this study, cultured normal human lung cells, obtained from histologically normal tissue from safety margins of surgically excised lung lesions, were analyzed.

\section{MATERIAL AND METHODS}

\subsection{Donors}

Specimen donors were tumor patients who underwent operative interventions at the Hospital of Halle University. Age, drug intake and smoking were not considered exclusion criteria. Written consents that tissue specimens can be used for cell culture purposes were signed whichwas approved by the ethical committee of Halle-Wittenberg University.The study did not interfere with the medical management at any time.

\subsection{Antibodies}

- Primary

rabbit polyclonal antibodies were raised against a recombinant protein corresponding to amino acids 1-70 mapping at the amine terminus of MRP1 of human origin.

\section{- $\quad$ Secondar $\mathrm{y}$ antibodies, labeled with FITC. \\ - $\quad$ Both}

primary and secondary antibodies were purchased from Santa Cruz Biotech. Inc. (Santa Cruz, USA)

\subsection{In-vitro culture of Normal Human Bronchial Epithelial Cells (NHBEC) from bronchial tissue}

- Normal tissue specimens were obtained from resected lung, proximal to the tumor. They were then immersed immediately into cold sterile buffer solution (Leibovitz L15-buffer; Biochrom, Berlin, Germany).

- Bronchial tissue was separated from the surrounding lung and cut into small pieces which were placed onto fibronectin-, collagen-and Bovine-SerumAlbumin pre-coated culture dishes containing L15-medium (Seromed, Berlin, Germany).

- $\quad$ Five minutes later, serumfree medium SFM (AECG-medium, PromoCell, Heidelberg, Germany) was applied.

- Over 2-3 weeks, cells grew out of the cultivated bronchial tissue pieces and became adherent to the upper 
surface of the coated culture dishes, until subtotal confluence (80-90\%) was reached (first generation).

- Culture medium was renewed every 48hours.

- Tested cells were mainly from the first generation.

\subsection{In-vitro culture of normal} peripheral lung cells

- Lung tissue distal to the bronchial tree was examined microscopically and proved to be free of bronchial epithelial cells.

- Normal peripheral lung tissue was resected and preserved directly in cold buffer (L15 Leibovitz buffer; Biochrom, Berlin, Germany).

- Pieces from the resected normal lung tissue were transferred onto uncoated culture dish (Techno Plastic Products TPP).

- Cultured tissues were maintained in serum-free AECG medium (PromoCell, Heidelberg, and Germany).

- Cell grew out and formed a subconfluent cell monolayer within 45weeks.

\subsection{Culture of lung tumor cells}

- A549 human lung cell line; a lung adenocarcinoma cell line with morphological AII cell characteristics; was used in this study.

- Cells were generously provided by Dr. F. Wiebel, Munich.

- All lung cancer cells were cultured in tissue culture flasks (Techno Plastic Products TPP, Trasadingen, Switzerland) in DMEM medium
(Gibco, Berlin), supplemented with $10 \%$ fetal calf serum (c.c. pro, Neustadt/W., Germany) and $1 \%$ penicillin/streptomycine (10000IE/ml).

- Medium was changed every 2-3 days.

\subsection{Viability assay}

- Cell viability and non-lethal concentrations of used chemicals were assesed by the colorimetric MTT assay.

- Briefly, the principle of the test depends on enzymatic conversion of substrate(MTT-reagent)into

chromogenic product (formazan)by cellular dehydrogenases with color change from yellow to blue in live cells.

2.7. Cell Treatment with the PGCOX pathway modulator and CDF transport-Assay

- The fluorescence dye 5,6carboxy-2 -7`-dichlorofluorescein

(CDF) is a specific MRP1 substrate that was engaged in a single cell functional assay of adherent cells for testing the transmembranous transport properties of MRP1 (Stehfest et al., 2005).

- COX-enzyme inhibitor (acetylated salicylate-1,2mM-Sigma) was added to the cultivated adherent NHBEC, PLC and A549 cells for 24 and $72 \mathrm{hrs}$. 
- Cells were then incubated with the MRP substrate $\mathrm{CDF}(4 \mu \mathrm{g} / \mathrm{ml})$ at $37^{\circ} \mathrm{C}$ for $4 \mathrm{hrs}$.

- Then, the cells were washed with buffer solution (PBS)after removing the medium containing the fluroscence substrate CDF.

- For imaging and measuring intracellular content of $\mathrm{CDF}$, the chamber slides were examined by an inverted microscope (Nikon Diaphot AFX-DX).

- Lung cells burdened with CDF were excited by UV light of 460nm.

- Emitted fluorescence signal passed through a 490nm emission filter and was registered by a photomultiplier tube.

- DSCAN soft ware (Amko Ltd) was used for the fluorescence excitation adjustment sowie data processing.

2.8. Interpretation of the performed experiments

- Presented data are results of at least three independent experiments.

- All data were expressed as mean \pm standard error (SE).

- Comparisons and statistical significance were performedusing $t-$ test.

\section{RESULTS \\ 3.1. Primary Human Lung Cell Cultures}

Histologically, normal lung resections were used as raw material to obtain serum free cultures of human lung cells i.e. a Normal Human Bronchial Epithelial Cell culture (NHBEC) from the proximal bronchial tree and a Peripheral Lung Cell culture (PLC) from distal parts of the human lung. These cultures were previously characterised as cultures of lung epithelial cells by immunocytochemistry. Outgrowth mono-layers from tissue material (generations) were taken as the main experimental skeleton in order to maintain a close resemblance to the tissue material.

\subsection{Immuno-localization of MRP1}

- Localization of MRP1 was analysed by indirect immunofluorescent staining.

- Methanol fixed cells were immune-stained with MRP1 antibodies after conduction of permobilization and non-specific blocking steps.

- MRP1 was localised in the cell membrane of all examined cells (figure 1). 

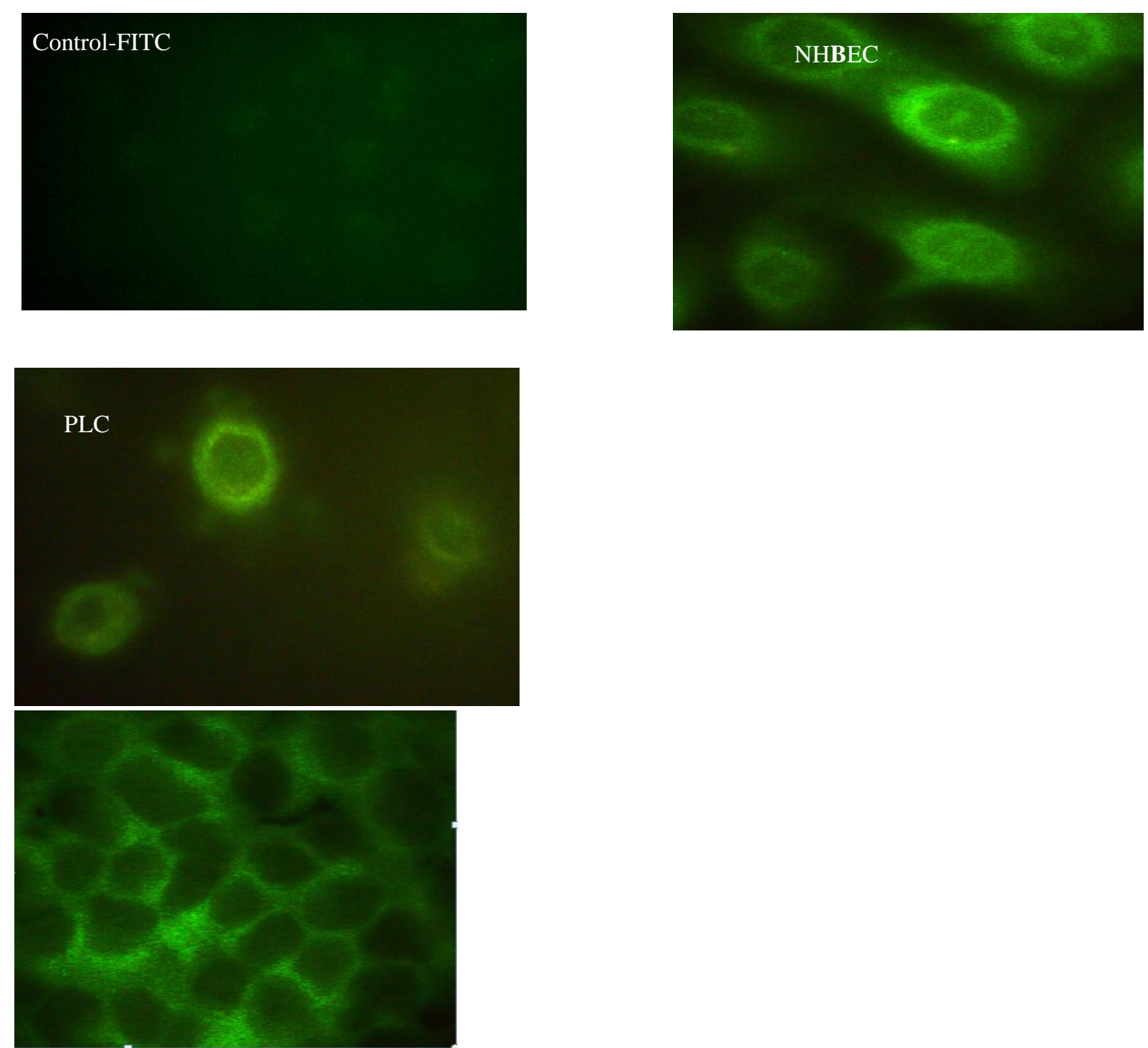

Fig. (1): Detection of MRP1 in NHBEC, PLC and A549 human lung cells using immunofluorescence microscopy.

3.3. Fluorescence imaging to monitor the effect of PG-COX

It has been proved that cellular distribution of MRP isoforms is not unique in both normal human lung cells and A549 lung tumor cells measured by immunofluorescence. Furthermore, substantial differences in the basic expression of MRP isoforms between these lung cells were observed. A549 cells exhibited a higher mRNA level for MRP1, 3 and 4 than NHBECs and PLCs. On the other hand, in A549 MRP5, mRNA was lower than the level in normal lung cells. NHBECs and PLC had a very similar pattern of mRNA system-related modulator on MRP1 transport function.

expression for these MRP is forms(Torky et al, 2008).

To translate MRP expression at both mRNA and protein levels to an observed functional event, a functional assay was designed to quantify MRP1 activity by the extrusion of fluorescence marker 5,6-carboxy-2'7'dichorofluorescein (CDF). For this purpose, attached cells were measured in non-cell destructive micro-method of fluorecence imaging where only a few number of attached cultured cells are 
needed to carry out transport studies (Stehfest et al., 2005).

For testing the potential modulatory influence of inflammatory mediators on MRP1-dependent CDF-transport NHBEC, PLC and A549 cell cultures pre-incubated with COX- enzyme inhibitor (acetylated salicylate) have been undertaken for experimental purposes. Lung cells were set onto precoated borosilicate cover glasses. Cells were incubated with acetylated salicylate (1mM, $2 \mathrm{mM}$ ) for 24 or $72 \mathrm{hrs}$. Efflux kinetics of CDF (transport activity of MRP1), were substantially reduced in all tested cells (figures2, 3 and 4).

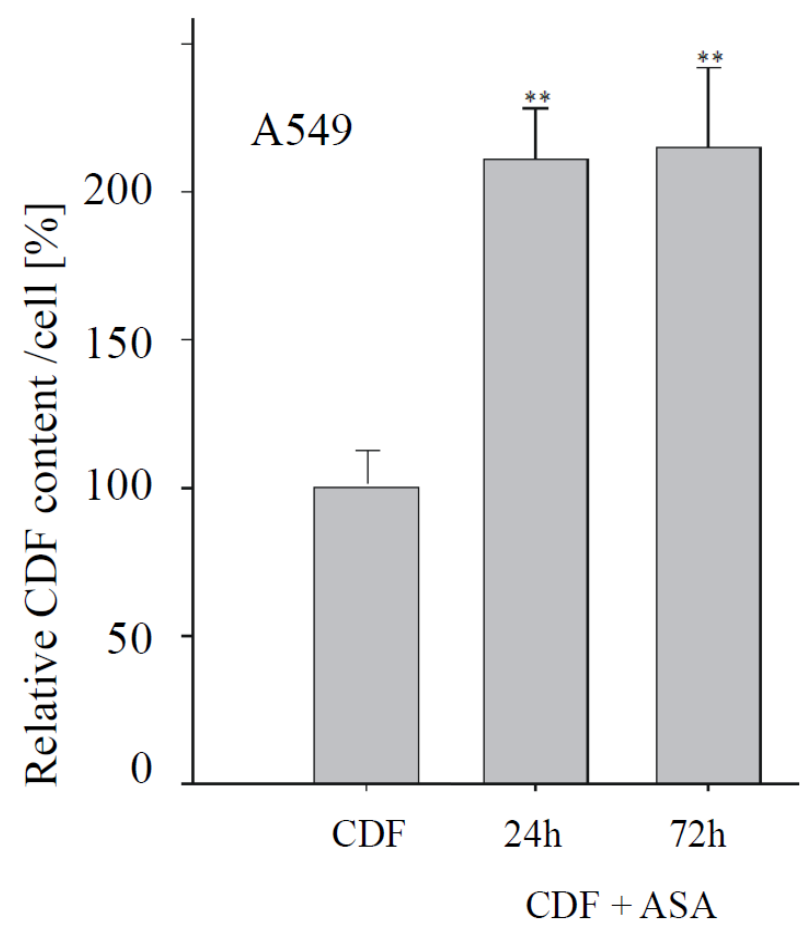

Fig. (2): Inhibitory effect of acetyl salicylic acid on MRP1 activity in A549 cell line. 


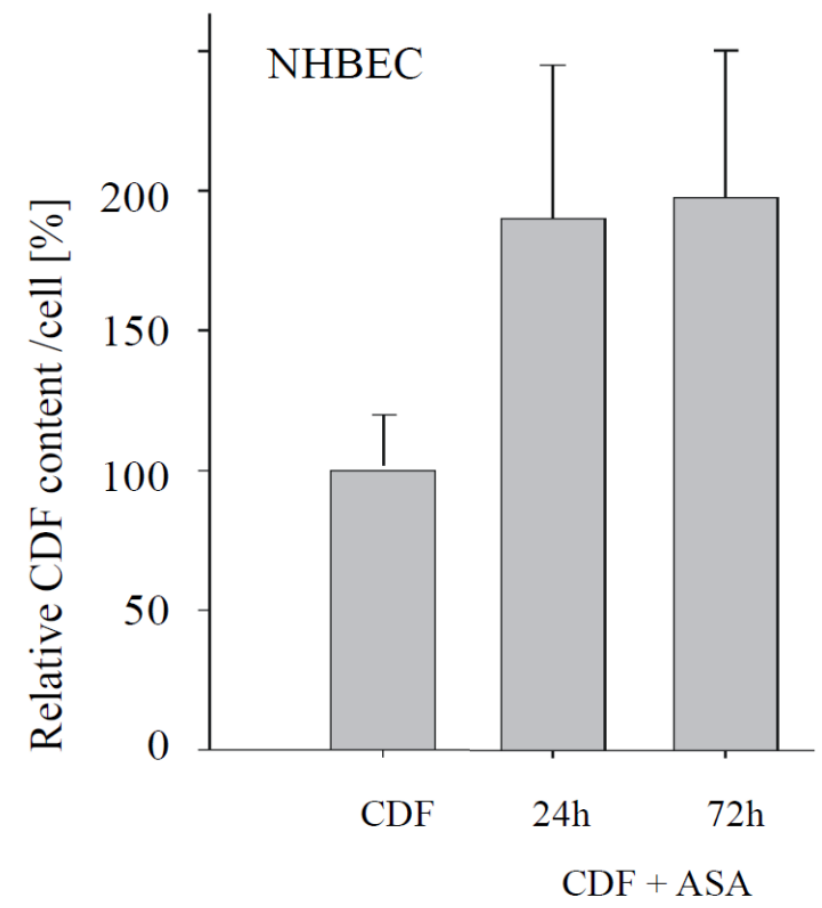

Fig. (3): Inhibitory effect of acetyl salicylic acid on MRP1 activity in NHBEC in culture.

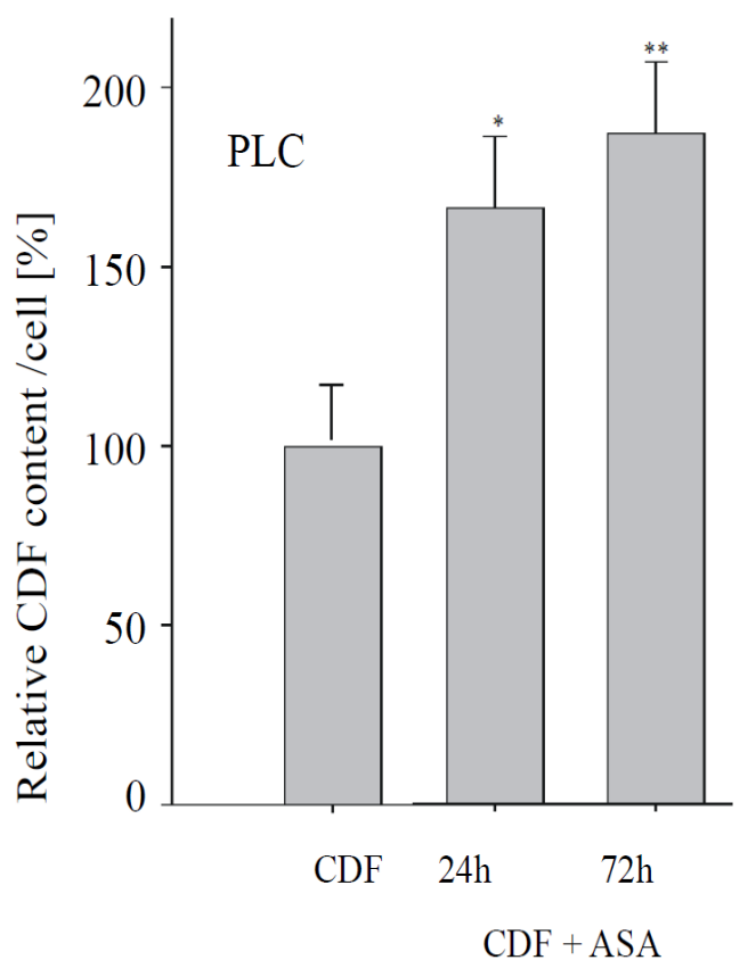

Fig. (4): Inhibitory effect of acetyl salicylic acid on MRP1 activity in PLC in culture.

Cytotoxicity of test substrates has been pre-testedusing MTT assay to determine nontoxic concentrations(table 1). 
Table 1: Cell viability treated with subtrates /modulators of MRP1activity.

\begin{tabular}{|c|c|c|c|c|}
\hline Substrate & Concentration & NBEC Viability (\%) & PLC Viability (\%) & A549 Viability (\%) \\
\hline \multirow[t]{3}{*}{ CDF } & $3 \mu \mathrm{g} / \mathrm{ml}$ & $95.7 \pm 2.0$ & $97.2 \pm 3.2$ & $97.2 \pm 3.0$ \\
\hline & $4 \mu \mathrm{g} / \mathrm{ml}$ & $95.6 \pm 3.8$ & $95.9 \pm 3.1$ & $84.0 \pm 5.9$ \\
\hline & $5 \mu \mathrm{g} / \mathrm{ml}$ & $33.5 \pm 6.8$ & $29.2 \pm 4.1$ & $44.3 \pm 10.2$ \\
\hline \multirow[t]{3}{*}{ ASA } & $1 \mathrm{mM}$ & $97.5 \pm 3.0$ & $96.7 \pm 8.0$ & $98.1 \pm 2.2$ \\
\hline & $2 \mathrm{mM}$ & $99.4 \pm 3.1$ & $95.7 \pm 3.5$ & $95.3 \pm 3.1$ \\
\hline & $5 \mathrm{mM}$ & $59.6 \pm 6.6$ & $47.6 \pm 5.2$ & $65.4 \pm 11.1$ \\
\hline
\end{tabular}

Cultured lung cells were treated with the test substance for $72 \mathrm{hrs}$. Tests were performed at least 3 times and results are presented as the means $\pm \mathrm{SE}$. Values shown are percents (\%) of untreated controls.

\section{DISCUSSION}

Inhalation is a very common route of exposure to many toxic xenobiotics; therefore, the respiratory tract is considered a target organ for their potential toxic effects. Lung-directed studies using human based material represent an important step to uncover mechanisms of many toxicopathological changes in the lung even on the cellular level.

Lung epithelium in direct contact with air possesses metabolic pathways for detoxification of inhaled xenobiotics that include phase I reaction catalyzed by cytochrome $\mathrm{P}$ 450 mono-oxygenase system and phase II catalyzed by glutathion S-transferase and quinon oxidoreductase(Guengerich, 1990; Gonzalez and Gelboin, 1994; Nagayoshi et al., 2004, Gana et al., 2019).

Tissue cultures from normal human lung are a very suitable model to generate primary human bronchial and peripheral lung cells. It has been proven that stable tissue adherence to the underlying culture surface is an important prerequisite for maintaining organotypic culture.

Cellular outgrowth from bronchial and peripheral lung tissue slices under serum-free conditions provided normal human lung cells for experimental purposes.Bronchial and peripheral lung cells behave differently with respect to morphology of cultured cells, general features of cultures to re-differentiate and responses to stressors beginning from the naturally occurring physiological mediators such as prostaglandins to toxic metals.

A substantial morphological redifferentiation of rodent, canine and human tracheal epithelial cells was reported for culture systems using airliquid interfaces that mimic physiological lung conditions. Johnson and colleagues, (1993) reported an enhanced sodium transport and aerobic pattern of metabolism in canine bronchial epithelial cells cultured invivo-like air-liquid conditions in contrast to controls cultivated under conventional conditions. Rat alveolar type II cells are promoted to express differentiated type II cell characteristics (lamellar bodies, tubular myelin) and biochemical functions (phosphatidylcholine secretion) (Khosa 
et al., 1996; Dobbs et al., 1997). Permeability parameters were better conserved in cultures maintained using transwell insert membranes (Roum et al., 2001).

Cells from both lung topographic regions responded to changes in culture conditions such as applications of the dry-wet configuration of cell culture. Cells regain a polarized nature and acquire a highly differentiated physiological shape. Mixed cell type culture from peripheral lung establishes "alveoli-like" structures that are of concern which can only occur when apoptosis and anti-apoptosis are active and are still controlled by a meaningful battery of regulating factors.

Regulation of MRPs is still unknown and their expression is not a fast event in the lung. Variation within the material from a single individual is astonishingly low and stressors from the side of ROS generation, toxic metals and inflammatory mediators have a relatively low impact compared to what is known for liver and for regulation of MDRs. Furthermore, inducers of xenobiotic metabolizing enzymes that appears to increase intracellular levels of metabolites affect transporter expression responsible for metabolite export. Alteration of functional activity of transporters might influence both kinetics and effects of inhaled toxins (Nagayoshi et al., 2004; Hao et al., 2019).

Therefore, MRPs expression and localization in lung cells under both classic and dry-wet culture conditions were investigated and for these purposes, cultures of NHBEC, PLC and A549 were used as a test tool.
MRP1 expression is confirmed in both tumor (Cole et al., 1992) normal cells as brain (Regina et al., 1998), liver (Keppler et al., 1996),lymphocytes (Legrand et al., 1996), intestine, kidney (Peng et al., 1999) and dendritic cells (Robbiani et al., 2000). MRP1 expression differs within different tissues, and shows adaptive response to surrounding circumstances through restriction to specific cell types to serve certain functions as in testicular Leydig and Sertoli cells to maintain low levels of estrogen metabolites (Stride et al., 1996; Flens et al., 1996; Qian et al., 2001). Similarly, human kidney glomeruli also express MRP1providing protective effect against cytotoxins (Scheffer et al., 2000; Wijnholds et al., 2000a).

In polarized epithelial cells, MRP1 is located mainly in basolateral membranes whereas other transporters such as P-glycoprotein, MRP2 and BCRP/ABCG2 are primarily apical membrane proteins. (Haimeur et al., 2004).

MRP1 was identified as a membrane protein in PLC,NHBEC, and A549 tumor cell line under both conventional culture condition and biphasic dry/wet configuration (NHBEC) as indicated by Confocal LASER Scanning Microscopy (CLSM) (Torky et al., 2005). These findings are homogenouswith asuggested lung protective function of MRP1 from airborne xenobiotics. Furthermore, intracellular membranes of particular cells expressed MRP1 under certain conditions(Van Luyn et al., 1998). Physiological function of subcellular MRP1 in relation to this subcellular 
location is not well understood (Haimeur et al., 2004).

Several different function assay systems measuring accumulation and efflux of radio-labelled or fluorescent xenobiotics have been useful not only for identifying substrates of MRP1 but also for studying the relative MRP1 transport activity in intact cells (Haimeur et al., 2004). Lehmann and other researchers, (2001) confirmed an expression of immune-reactive MRP1 protein in cultured human lung cells.

Messenger RNA expression gives an idea about protein regulation in pretranslational stages but is not enough for functional characterization. This problem could not be overcome by Classical Western blotting for MRPs. Therefore, a non-destructive quantitative fluorescence microscopy assay for functional characterization of MRP1-mediated transport was established across lung epithelium. This micro-method represents a promising analytical tool to understand mRNA transformation into functionally active protein (Stehfest et al., 2005).

The MRP1 activityis closely related to cellular glutathion content and is involved in GSH-dependent xenobiotictransport (Borst et al., 2000; Gana et al., 2019).

To check both the sensitivity and specificity of the assay, glutathione pool in tumor cell lines A549, H358 and H322was manipulated by an inhibitor, buthionine sulfoximine (BSO), and a promoter, N-acetyl cystein (NAC) of the glutathione synthesis. BSO reduced MRP1 transport activity through inhibition of glutathione synthesis. NAC pre- incubated cells exhibited anenhanced MRP1-mediated transport due to increased cellular glutathion levels (Stehfest et al, 2007).

Physiological function of MRP1 comprises secretion of prostaglandin (PGA2) and leukotrienes (LTC4, LTD4, LTE4), efflux of glutathione disulfide as well as transport of organic anions and other substances conjugated to glutathione, glucuronide, or sulphate (Jedlitschky et al., 1996; Renes et al., 2000; Hao et al, 2019).

Data clearly show that bronchial and peripheral lung cells react differently towards prostaglandins. Bronchial cells react while peripheral lung cells and lung tumor cells don't and PGE2 is active while PGF $2 \alpha$ is inactive. MRP1, 3 and 5 are upregulated by PGE2 which was applied in non toxic concentrations; an effect that needs time to develop. Taken together, it must be expected that inflammatory mediators are modulators for MRP expression (Torky et al., 2008).

This study demonstrated that acetyl salicylic acid might modify MRP1 activity in human lung cells. It could suppress MRP1- mediated efflux transport in bronchial epithelial cells, PLC as well as A549 tumor cells.Together, cell membrane situation of MRP1 used as a test tool adds to cellular ability to withstand opposing environmental factors and may also be the trigger zone for chemotherapeutic resistance in tumor cells through rapid extrusion of such agents via the membrane situated protein pumps. Therefore, an enhanced therapeutic scope to develop a potent reverser of drug resistance may be introduced by 
interacting with MRP1 activity to treat chemo-resistant MRP1-overexpressing malignancies.

\section{REFERENCES}

Belinsky MG, Bain LJ, Balsara BB, Testa JR , Kruh GD (1998). Characterization of MOAT-C and MOAT-D, new members of the MRP/cMOAT subfamily of transporter proteins. J. Natl. Cancer Inst. 90: 1735-1741.

Belinsky MG, Chen ZS, Shchaveleva I, Zeng H, Kruh GD (2002). Characterization of the drug resistance and transport properties of multidrug resistance protein 6 (MRP6, ABCC6). Cancer Res. 62:6172-6177.

Borst P, Evers R, Kool M, Wijnholds J (1999). The multidrug resistance protein family. Biochem.Biophys.Acta. 1461:347357.

Borst P, Evers R, Kool M, Wijnholds J (2000). A family of drug transporters: the Multidrug Resistance-associated Proteins. J.Natl.Cancer Inst. 92:1295-1302.

Cole SPC, Bhardwaj G, Gerlach JH, Mackie JE, Grant CE, Almquist KC, Stewart Aj Kurtz EU, Duncan AMV, Deeley RG (1992). Overexpression of a transporter gene in a multidrug-resistant human cancer cell line. Science. 258: 1650-1654.

Dobbs LG, Pian MS, Maglio M, Dumars S, Allen L (1997). Maintenance of the differentiated type II cell phenotype by culture with an apical air surface. Am.J.Physiol. 273:L347-354.

Flens MJ, Zaman GJ, van der Valk P, Izquierdo MA, Schroeijers AB, Scheffer GL, van der Groep P, de Haas M, Meijer CJ, Scheper RJ. (1996). Tissue distribution of the multidrug resistance protein. Am.J.Pathol. 148:1237-1247.

Funk CD (2001).Prostaglandins and leukotrienes: advances in eicosanoid biology. Science. 294:1871-1875. Review.

Gana CC, Hanssen KM, Yu DMT, Flemming CL, Wheatley MS, Conseil G, Cole SPC, Norris MD, Haber M, Fletcher JI (2019). MRP1 modulators synergize with buthionine sulfoximine to exploit collateral sensitivity and selectively kill MRP1-expressing cancer cells.Biochem.Pharmacol. 168:237248.

Gonzalez FJ, Gelboin HV (1994). Role of human cytochromes P450 in the metabolic activation of chemical carcinogens and toxins. Drug Metab.Rev. 26:165-183.

Guengerich FP (1990). Purification and characterization of xenobiotics metabolizing enzymes from lung tissue. Pharmacol.Ther. 45:299307.

Haimeur A, Conseil G, Deeley RG, Cole SPC (2004). The MRPRelated and BCRP/ABCG2 multidrug resistance proteins: biology, substrate specificity and regulation. Current Drug Metabolism. 5:21-53 Review. 
Hao Q, Gudapati V, Monsel A, Park JH, Hu S, Kato H, Lee JH, Zhou L, He H, Lee JW (2019). Mesenchymal Stem Cell-Derived Extracellular Vesicles Decrease Lung Injury in Mice. J.Immunol. pii: ji1801534. doi: 10.4049/jimmunol.1801534. [Epub ahead of print].

Hirrlinger J, Konig J, Dringen $\mathbf{R}$ (2002). Expression of mRNAs of multidrug resistance proteins (Mrps) in cultured rat astrocytes, oligodendrocytes, microglial cells and neurones. Neurochem.,82:716719.

Jedlitschky G, Leier I, Buchholz U, Barnouin K, Kurz G, Keppler D (1996). Transport of glutathione, glucuronate, and sulfate conjugates by the MRP gene-encoded conjugate export pump. Cancer Res.,56:988-994.

Jedlitschky G, Keppler D (2002). Transport of leukotriene C4 and structurally related conjugates. Vit.Horm., 64:153-184.Review.

Johnson LG, Dickman KG, Moore KL, Mandel LJ, Boucher RC (1993). Enhanced $\mathrm{Na}+$ transport in an air-liquid interface culture system. Am.J.Physiol. 264:L560565.

Kam PC, See AU (200). Cyclooxygenase isoenzymes: physiological and pharmacological role. Anaesthesia. 55:442-449. Review.

Kartenbeck J, Leuschner U, Mayer R and Keppler D (1996). Absence of the canalicular isoform of the MRP gene-encoded conjugate export pump from the hepatocytes in Dubin-Johnson syndrome. Hepatology, 23:1061-1066.

Keppler D, Leier I, Jedlitschky G, Mayer R, Buchler M (1996). The function of the multidrug resistance proteins (MRP and cMRP) in drug conjugate transport and hepatobiliary excretion. Adv.Enz.Regul.,36:17-29.

Kiuchi Y, Suzuki H, Hirohashi T, Tyson $C A$ and Sugiyama $Y$ (1998). cDNA cloning and inducible expression of human multidrug resistance associated protein 3 (MRP3). FEBS Lett., 433: $149-152$.

Klein-Nulend J, Semeins CM, Burger EH (1996). Prostaglandin mediated modulation of transforming growth factor-beta metabolism in primary mouse osteoblastic cells in vitro.J.Cell Physiol.,168:1-7.

Kohsa K, Yamada H, Sugihara H (1996). Influence of air exposure treatment on alveolar type II epithelial cells cultured on extracellular matrix. Ell.Struct.Funct.,21:81-89.

Kool M, de Haas M, Scheffer GL, et al. (1997). Analysis of expression of cMOAT (MRP2), MRP3, MRP4, and MRP5, homologues of the multidrug resistance-associated protein gene (MRP1), in human cancer cell lines. Cancer Res. 57:3537-3547.

Kool M, van der Linden M, de Haas M, Scheffer GL, de Vree JM, Smith AJ, Jansen G, Peters GJ, 
Ponne N, Scheper RJ, Elferink RP, Baas $F$ and Borst $P$ (1999). MRP3, an organic anion transporter able to transport anti-cancer drugs. Proc.Natl.Acad.Sci.,USA, 96:69146919.

König J, Nies AT, Cui Y, Leier I, Keppler D (1999). Conjugate export pumps of the multidrug resistance protein (MRP) family: localization, substrate specificity, and MRP2-mediated drug resistance.

Biochem.Biophys.Acta.,1461:377394.Review

Kruh GD, Belinsky MG (2003).The MRP family of drug efflux pumps. Oncogene. 22:7537-7552. Review.

Lee k, Belinski M G, Bell D W, Testa J R, Kruh G D (1998). Isolation of MOAT-B, a widely expressed multidrug resistance-associated protein/canalicular multispecific organic anion transporter-related transporter. Cancer Res.,58:27412747.

Lee K, Klein-Szanto AJ, Kruh GD (2000). Analysis of the MRP4 drug resistance profile in transfected NIH3T3 cells. J. Natl. Cancer Inst., 92: 1934-1940.

Legrand O, Perrot JY, Tang RP, Simonin G, Gurbuxani S, Zittoun R, Marie JP (1996). Expression of the multidrug resistance-associated protein (MRP) mRNA and protein in normal peripheral blood and bone marrow haemopoietic cells. Br.J.Haematol., 94:23-33.

Lehmann T, Kohler C, Weidauer E, Taege C, Foth H (2001).
Expression of MRP1 and related transporters in human lung cells in culture. Toxicology,167:59-72.

Leier I, Jedlitschky G, Buchholz U, Cole SP, Deeley RG, Keppler D (1994). The MRP gene encodes an ATP-dependent export pump for leukotriene $\mathrm{C} 4$ and structurally related conjugates.

J.Biol.Chem.,269:27807-27810

Liu B1, Qu L, Tao H (2009).Cyclooxygenase 2 up-regulates the effect of multidrug resistance.Cell Biol.Int., 16;34(1):21-25.

McAleer C, Breen M A, White N L, Matthews N (1999). pABC11 (MOAT-C and MRP5), a member of the ABC family of proteins, has anion transporter activity but does not confer multidrug resistance when overexpressed in human embryonic kidney 293 cells. J.Biol.Chem.,274:23541-23548.

Miller DS, Nobmann SN, Gutmann H, Toeroek M, Drewe J, Fricker G (2000). Xenobiotic transport across isolated brain microvessels studied by confocal microscopy. Mol.Pharmacol.,58:1357-1367.

Mitani A, Nakahara T, Sakamoto K, Ishii $K$ (2003). Expression of multidrug resistance protein 4 and 5 in the porcine coronary and pulmonary arteries. Eur.J.Pharmacol.,466:223-224.

Mottino AD, Hoffman T, Jennes L and Vore M. (2000). Expression and localization of multidrug resistant protein mrp2 in rat small intestine. 
J.Pharmacol.Exp.Ther.,293(3):717723.

Müller M. (2002). Fifty one Human ATP-Binding

Cassette

Transporters. Available at: http://humanabc.4t.com/humanabc. htm.

Nagayoshi K, Nemoto T, Yokoyama S, Yamashita F, Hashida $M$ (2004). Effect of polycyclic aromatic hydrocarbons on generation and efflux of glutathione conjugates in primary cultured alveolar epithelial cells. Drug Metab Pharmacokinet. 19:407-412.

Nies AT, Spring H, Thon WF, Keppler D and Jedlitschky G (2002). Immunolocalization of multidrug resistance protein 5 in the human genitourinary system. J.Urol., 167: 2271-2275.

Nies AT, Jedlitschky G, Konig J, Herold-Mende C, Steiner HH, Schmitt HP, Keppler D (2004). Expression and immunelocalization of the multidrug resistance proteins, MRP1-MRP6 (ABCC1-ABCC6), in human brain. Neuroscience. 129:349-360.

\section{Peng KC, Cluzeaud F, Bens M, Van} Huyen JPD, Wioland MA, Lacave R, Vandewalle A (1999). Tissue and cell distribution of themultidrug resistance-associated protein (MRP) in mouse intestine and

kidney.

J.Histochem.Cytochem., 47:757767.

Qian YM, Song WC, Cui H, Cole SP, Deeley RG (2001). Glutathione stimulates sulfated estrogen transport by multidrug resistance protein 1. J.Biol.Chem.,276:64046411.

Quarles LD, Haupt DM, Davidai G, Middleton JP (1993). Prostaglandin F2 alpha-induced mitogenesis in MC3T3-E1 osteoblasts: role of protein kinaseC-mediated tyrosine phosphorylation. Endocrinology. 132: 1505-1513.

Raemisch A, Torky AR, Hofmann S, Foth $H$ (2005).Modulation of multidrug resistance proteins by prostaglandins in human lung cells. Am.J.Physiol., Lung Cellular and Molecular Physiology, submitted.

Regina A, Koman A, Piciotti M, Hafny BE, Center MS, Bergmann R, Couraud PO, Roux F (1998). Mrp1 multidrug resistance-associated protein and $\mathrm{P}$ glycoprotein expression in rat brain microvessel endothelial cells. J.Neurochem., 71:705-715.

Renes J, de Vries EG, Jansen PL, Muller M (2000). The (patho)physiological functions of the MRP family. Drug Resist.Updat.,3:289-302.

Robbiani DF, Finch RA, Jager D, Muller WA, Sartorelli AC, Randolph GJ (2000). The leukotriene $\mathrm{C}(4)$ transporter MRP1 regulates CCL19 (MIP-3beta, ELC)-dependent mobilization of dendritic cells to lymph nodes. Cell 103:757-768.

Rost D, Mahner S, Sugiyama Y and Stremmel W (2002). Expression and localization of the multidrug 
resistance-associated protein 3 in rat small and large intestine. Am.J.Physiol.Gastrointest. Liver Physiol., 282:G720-726.

Roum JH, Aledia AS, Carungcong LA, Kim KJ, Borok Z (2001). Extracellular glutathione inhibits oxygen-induced permeability changes in alveolar epithelial monolayers. Appl.Physiol.,91:748754.

Roy U, Barber P, Tse-Dinh YC, Batrakova EV, Mondal D and Nair M (2015). Role of MRP transporters in regulating antimicrobial drug inefficacy and oxidative stress-induced pathogenesis during HIV-1 and TB infections. Front.Microbiol., Reviewhttps://doi.org/10.3389/fmic b.2015.00948.

Sampath J, Adachi M, Hatse S, Naesens L, Balzarini J, Flatley RM, Matherly LH, Schuetz JD (2002). Role of MRP4 and MRP5 in biology and chemotherapy. AAPS Pharm.Sci.,4:E14. Review(http://www.aapspharmsci.o rg).

Schaub TP, Kartenbeck J, König J, Vogel O, Witzgall R, Kriz W and Keppler D (1997). Expression of the conjugate export pump encoded by the mrp2 gene in the apical membrane of kidney proximal tubules. J.Am.Soc.Nephrol.,8:12131221.

Scheffer GL, Kool M, Heijn M, de Haas M, Pijnenborg AC, Wijnholds J, van Helvoort A, de Jong MC, Hooijberg JH, Mol $C A$, van der Linden $M$, de Vree
JM, van der Valk P, Elferink RP, Borst P, Scheper RJ (2000). Specific detection of multidrug resistance proteins MRP1, MRP2, MRP3, MRP5, and MDR3 Pglycoprotein with a panel of monoclonal antibodies. Cancer Res.,60:5269-5277.

Scheffer GL, Kool M, de Haas M, de Vree JM, Pijnenborg AC, Bosman DK, Elferink RP, van der Valk P, Borst P, Scheper RJ (2002). Tissue distribution andinduction of human multidrug resistant protein 3 . Lab.Invest.,82:193-201.

Stehfest E, Torky AR, Glahn F, Foth H (2005). Non destructive micromethod for MRP1 functional assay in human lung tumor cells. Arch Toxicol, In press.

St-Pierre MV, Serrano MA, Macias RI, Dubs U, Hoechli M, Lauper U, Meier PJ, Marin JJ. (2000). Expression of members of the multidrug resistance protein family in human term placenta. Am.J.Physiol.Regul. Integr.Comp.Physiol.,279:R14951503.

Stride BD, Valdimarsson G, Gerlach JH, Wilson GM, Cole SP, Deeley RG (1996). Structure and expression of the messenger RNA encoding the murine multidrug resistance protein, an ATP-binding cassette transporter. Mol.Pharmacol.,49:962-971.

Suzuki T, Sasaki H, Kuh HJ, Agui M, Tatsumi Y, Tanabe S, Terada M, Saijo N, Nishio K (2000). Detailed structural analysis on both 
human MRP5 and mouse mrp5 transcripts. Gene.242:167-173.

Teodori E, Dei S, Floriddia E, Perrone MG, Manetti D, Romanelli MN, Contino M, Colabufo NA (2015). Arylamino Esters As P-Glycoprotein Modulators: SAR Studies to Establish Requirements for Potency and Selectivity. Chem.Med.Chem.,10(8):13391343.

Torky AR, Stehfest E Raemisch A, Viehweger $\mathbf{K}$, Täge $C$, Foth $H$ (2005). Immuno-histochemical detection of MRPs in human lung cells in culture. Toxicology Letters. 207:437-450.

Uchiumi T, Hinoshita E, Haga S, Nakamura T, Tanaka T, Toh S, Furukawa M, Kawabe T, Wada M, Kagotani K, Okumura $\mathbf{K}$, Kohno K, Akiyama S, Kuwano M (1998). Isolation of a novel human canalicular multispecific organicanion transporter, cMOAT2/MRP3, and its expression in cisplatin-resistant cancer cells with decreased ATPdependent drug transport. Biochem.Biophys.Res.Commun.,25 2:103-110.

Van Aubel RA, Smeets PH, Peters JG, Bindels RJ, Russel FG (2002). The MRP4/ABCC4 gene encodes a novel apical organic anion transporter in human kidney proximal tubules: putative efflux pump for urinary cAMP and cGMP.J.Am.Soc.Nephrol., 13:595603.
Van Luyn MJ, Muller M, Renes J, Meijer C, Scheper RJ, Nienhuis EF, Mulder NH, Jansen PL, De Vries EG (1998). Transport of glutathione conjugates into secretory vesicles is mediated by the multidrug-resistance protein 1 . Int.J.Cancer,76:55-62.

Wijnholds J, deLange EC, Scheffer GL, van den Berg DJ, Mol CA, van der Valk $M$, Schinkel AH, Scheper RJ, Breimer DD, Borst P (2000a). Multidrug resistance protein 1 protects the choroid plexus epithelium and contributes to the blood-cerebrospinal fluid barrier. J.Clin.Invest.,105:279-285.

Wijnholds J, Mol CA, van Deemter L, de Haas M, Scheffer GL, Baas F, Beijnen JH, Scheper RJ, Hatse S, De Clercq E, Balzarini J, Borst $P$ (2000b). Multidrug-resistance protein 5 is a multispecific organic anion transporter able to transport nucleotide analogs. Proc.Natl.Acad.Sci. USA.,97:74767481.

Zeng H, Liu G, Rea PA, Kruh GD (2000). Transport of amphipathic anions by human multidrug resistance protein 3. Cancer Res. 60:4779-4784.

Ziemann C, Schafer D, Rudell G, Kahl GF, Hirsch-Ernst KI (2002). The cyclooxygenase system participates in functional mdrlb overexpression in primary rat hepatocyte cultures.Hepatology. 35:579-588. 


\title{
الملخص العربى
}

\section{تثبيط البروتين المرتبط بمقاومة العقاقير المتعددة بواسطة حامض السليسليك في خلايا الرئة البشرية المستزرعة}

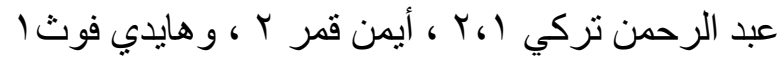 \\ ا معهد علم السموم البيئية ، جامعة هالي ، ألمانيا \\ r قسم الطب الشرعي و السموم الإكلينيكية ، كلية الطب ، جامعة حلو ان ، مصر
}

تعد البروتينات المرتبطة بمقاومة العقاقير المتعددة ( MRP) أعضـاء في مجموعـة الربط بمركب ثناثي

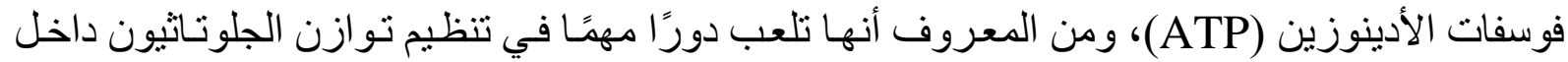

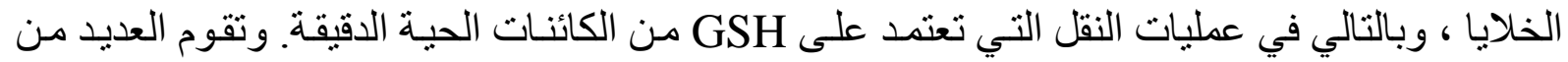
المركبات الخطرة في الهو اء بتحفيز تفاعلات الالتهاب في الرئة ويشتبه في أنها تلعب دورًا كبيرًا في بده أو تعزيز تكوين الأور ام.

وقد أولينا الإهتمام بتوضيح ما إذا كانت مضادات البروستاجلاندين تقوم بتعديل وظيفة هذه البروتينات في

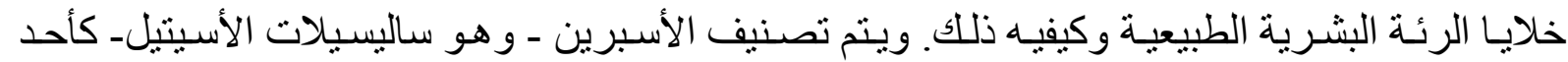

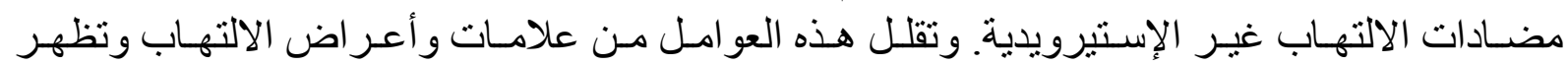

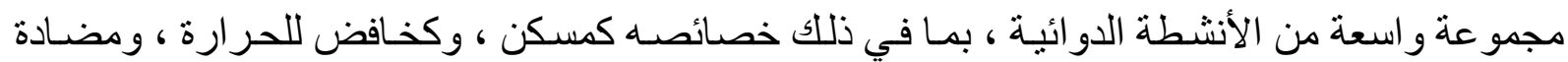
لتجمع الصفائح الدموية.

ويحفز نظـام الأكسدة الحلقيـة (COX) الحـد مـن المعدل في تخليق البروستانوئيدات (البروستاجلاندين كما يثارك أيضًا في مقاومة العقاقير وسوء التشخيص للعديد من الأور ام. وترجع قدرة الأسبرين

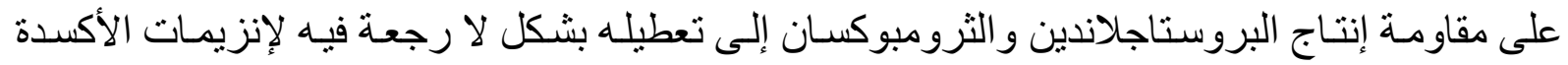

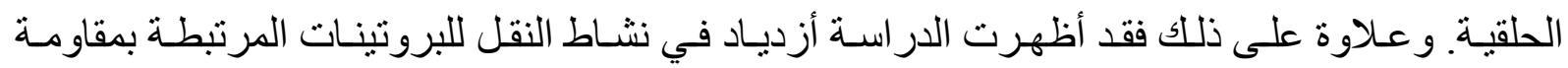
العقاقير في الخلايـا الظهاريـة للثـعب الهو ائيسة البشـرية الطبيعيـة (NHBEC) وخلايـا الرئـة المحيطيـة وخلايا الرئة الورمية (PLC)

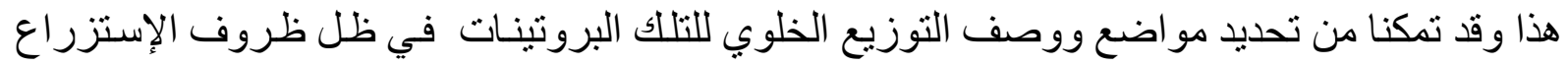
الخلوي القياسية لكل من الخلايا الظهارية للشعب الهو ائية البشرية الطبيعية وخلايا الرئة المحيطية وخلايا الرئة الورمية باستخدام المجهر المناعي غير المباشير.

وبإمكان مثبطات إنزيمات الأكسدة الحلقية (حمض الساليسليك أسيد ، r مم ) أن تقلل بشكل كبير من

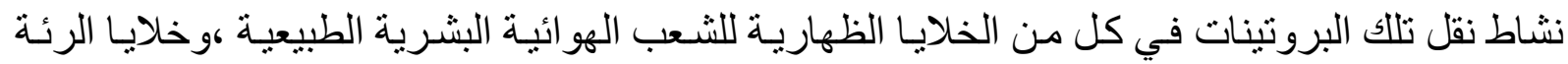

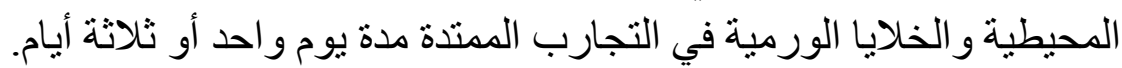

